\title{
CULTIVANDO A ARTE DE SERVIR
}

IsabelAmélia Costa Mendes ${ }^{1}$

$\mathrm{Na}$ sua compreensão mais ampla, Arte é "todo conjunto de regras capazes de dirigir uma atividade humana..." ${ }^{(1)}$ Platão assim postulava a arte, não estabelecendo diferenciação entre arte e ciência.

O serviço é uma forma de arte que precisamos cultivar. Em termos de impacto competitivo é com esse significado que o serviço alcança os melhores níveis de qualidade, ou seja, a excelência ${ }^{(2)}$.

Estamos vivenciando a Era dos Serviços. Os líderes de organizações prestadoras de serviços tomam para si a responsabilização singular com referência a clientes. Também os trabalhadores envolvidos interna ou externamente com a organização passam a constituir o foco dessa responsabilização, uma vez que a excelência de seus préstimos depende de fatores que determinam sua valorização como pessoas.

Vista sob a perspectiva platônica, a Enfermagem fundamenta suas atividades na arte dispositiva ou imperativa, ou seja, conduz suas ações com base no conhecimento. Mas, as ações de enfermagem além de integrarem a arte liberal (direcionada para o trabalho da razão), integram também a arte de servir e, neste particular, a saga dessa profissão é rica de incidências que ensejam 0 ato de servir.

Compete aos líderes da enfermagem propiciar condições para que os nossos trabalhadores recorram ao âmago de seu ser na busca de recursos que lhes possibilitem mais compreensão e criatividade. Que essa busca seja acompanhada e traga energias decorrentes da generosidade.

Com esta bagagem o trabalhador terá mais qualidade de vida, sendo capaz de exercitar o ato de servir como arte. Seus reflexos atingirão diretamente o cliente que, além do cuidado competente, sentirá que sua dignidade como pessoa está preservada.

A nossa missão é esta: servir para promover o desenvolvimento do potencial pessoal e profissional de todos os seres humanos que nos circundam, para que eles possam reproduzir o exemplo que tiveram e alcançar os benefícios esperados.

\section{REFERÊNCIAS BIBLIOGRÁFICAS}

1. Abbagnano N. Dicionário de filosofia. $4^{a}$ ed. São Paulo (SP): Martins Fontes; 2000.

2. Albrecht K. Revolução nos serviços: como as empresas podem revolucionar a maneira de tratar os seus clientes. São Paulo (SP): Pioneira Thomson Learning; 2002.

\footnotetext{
${ }^{1}$ Editor da Revista Latino-Americana de Enfermagem, Diretor, Professor Titular da Escola de Enfermagem de Ribeirão Preto, da Universidade de São Paulo, Centro Colaborador da OMS para o desenvolvimento da pesquisa em enfermagem, Brasil, e-mail: iamendes@eerp.usp.br
} 